\title{
Cloning and heterologous expression of the gene for BLIP-II, a $\beta$-lactamase-inhibitory protein from Streptomyces exfoliatus SMF19
}

\author{
Hyeon Ung Park and Kye Joon Lee
}

Department of

Microbiology, College of

Natural Sciences and

Research Center for

Molecular Microbiology,

Seoul National University,

Seoul 151-742, Korea

\begin{abstract}
Author for correspondence: Kye Joon Lee. Tel: +82 2880 6705. Fax: +82 28829285 or +8228884911 . e-mail : lkj12345@plaza.snu.ac.kr
\end{abstract}

\begin{abstract}
A $\beta$-lactamase-inhibitory protein (BLIP-II) was purified from the culture filtrate of Streptomyces exfoliatus SMF19 and its N-terminal amino acid sequence was determined. A clone containing the gene encoding BLIP-II (bliB) was selected from a cosmid library by colony hybridization using an oligonucleotide probe based on the $\mathrm{N}$-terminal amino acid sequence of BLIP-II. The bliB gene was isolated and sequenced. Analysis of the nucleotide sequence revealed that the gene consists of $1116 \mathrm{bp}$ and encodes a mature protein of 332 amino acids preceded by a 40 amino acid signal sequence. bliB, expressed under the control of the T7 promoter in Escherichia coli, was accumulated in an inactive form in inclusion bodies, but $\beta$-lactamase-inhibitory activity was recovered after refolding. In addition, bliB was heterologously expressed in Streptomyces lividans TK24 using the me/C1 promoter. The BLIP-II protein produced in recombinant strains of $S$. lividans was secreted into the culture supernatant in a biologically active form.
\end{abstract}

Keywords: Streptomyces exfoliatus, $\beta$-lactamase-inhibitory protein, cloning, heterologous expression

\section{INTRODUCTION}

Widespread clinical use of $\beta$-lactam antibiotics has caused a continuous increase in the incidence of infections due to pathogenic bacteria resistant to these antibiotics (Neu, 1992). $\beta$-Lactamases showing various substrate specificities have been identified from the resistant isolates (Abraham, 1983). $\beta$-Lactamase inhibitors of microbial origin have also been identified and some of them, for example clavulanic acid (Brown et al., 1976), olivanic acid (Butterworth et al., 1979) and thienamycin (Kahan et al., 1979) have been used clinically. A protein that inhibited the $\beta$-lactamase of Staphylococcus aureus was first isolated from Streptomyces gedaensis (Hata et al., 1972). Another protein (BLIP) inhibiting various $\beta$-lactamases was characterized from the culture filtrate of Streptomyces clavuligerus, and showed $K_{\mathrm{i}}$ values in the nanomolar to picomolar range (Doran et al., 1990; Strynadka et al., 1994). The interaction between purified BLIP and the $\beta$-lactamase

Abbreviation: BLIP, $\beta$-lactamase-inhibitory protein.

The GenBank accession number for the sequence determined in this work is U97057. of Escherichia coli (pUC) was noncovalent, with an estimated 1:1 molar stoichiometry (Doran et al., 1990). The corresponding gene, $b l i$, encoded a mature protein with a deduced sequence of 165 amino acids $\left(M_{r} 17523\right)$ and a 36 amino acid leader peptide.

$\mathrm{X}$-ray crystallographic analysis revealed that BLIP was a relatively flat molecule with an unique fold, comprising tandemly repeated 76 amino acid domains, each containing a helix--loop-helix motif. The molecular interaction between $\beta$-lactamase RTEM- 1 and BLIP was determined by establishing the structure of the complex, and a mechanism to explain the inhibiting effect of BLIP was proposed (Strynadka et al., 1996).

Recently, $\beta$-lactamase-inhibitory proteins (BLIP-I and BLIP-II) were found in culture supernatants of Streptomyces exfoliatus SMF19 (Kim et al., 1991; Kim \& Lee, 1994). Inhibition by BLIP-I ( $48 \mathrm{kDa})$ was uncompetitive, whilst that of BLIP-II $(33 \mathrm{kDa})$ was noncompetitive; the inhibition constants were $0.62 \times 10^{-4}$ and $2.74 \times 10^{-1} \mu \mathrm{mol}$, respectively. Here, we report the cloning and analysis of a gene encoding BLIP-II, and heterologous expression of the gene in $E$. coli and Streptomyces lividans. 


\section{METHODS}

Bacterial strains, cosmid and plasmids. S. exfoliatus SMF19 (Kim et al., 1991; Kim \& Lee, 1994) was the source of genomic DNA from this species. S. lividans TK24 (Hopwood et al., 1985) was used as a host strain for the plasmid pIJ702 (Katz et al., 1983) and for expression of the bliB gene. E. coli DH5a (Hanahan, 1983) was used to propagate recombinant cosmids and plasmids. E. coli Top10F' (Invitrogen) was used as host for pZero-2 (Invitrogen). pWE15 (Wahl et al., 1987) was used to construct a genomic library of $S$. exfoliatus SMF19.

For subcloning, the vectors pBluescript II $\mathrm{KS}(+)$ (Stratagene), pZero-2 and pUC18 (Yanisch-Perron et al., 1985) were used. E. coli BL21 (DE3), a lysogen bearing the bacteriophage T7 polymerase gene under the control of the lacUV5 promoter, was used for heterologous expression of bliB cloned in pET3a (Studier \& Moffatt, 1986); S. lividans was used for heterologous expression of bliB in pIJ702.

Media and culture conditions. Strains of Streptomyces spp. were maintained on Bennett agar (Jones, 1949) and spore suspensions were stored in $20 \%(\mathrm{v} / \mathrm{v})$ glycerol at $-20^{\circ} \mathrm{C}$. YEME and R2YE media (Hopwood et al., 1985) were used to grow streptomycetes for DNA manipulation. Strains of $E$. coli were grown in LB medium with ampicillin $\left(60 \mu \mathrm{g} \mathrm{ml}^{-1}\right)$ or kanamycin $\left(50 \mu \mathrm{g} \mathrm{ml}^{-1}\right)$ for plasmid or cosmid maintenance (Sambrook et al., 1989). To prepare seed cultures of Streptomyces spp., seed medium was inoculated with spore stocks in $20 \%$ glycerol and cultured at $30^{\circ} \mathrm{C}$ on a rotary shaker (150 r.p.m.). Seed medium contained (w/v): $2 \%$ glucose, $1.6 \%$ soytone, $0.3 \%$ peptone and $0.1 \% \mathrm{CaCO}_{3}$. The seed culture was used to inoculate BLI production medium containing $(\mathrm{w} / \mathrm{v}): 1.5 \%$ glucose, $1.5 \%$ soytone, $0.2 \%$ yeast extract, $0.12 \% \mathrm{~K}_{2} \mathrm{HPO}_{4}, 0.06 \% \mathrm{CaCO}_{3}, 0.001 \% \mathrm{CoCl}_{2}$ and $0.0025 \% \mathrm{FeSO}_{4}$. Production cultures were grown in a glass jar fermenter (model KF-5L; Korea Fermenter) at $30^{\circ} \mathrm{C}$ for $50 \mathrm{~h}$; agitation and aeration were 300 r.p.m. and 1 vol. vol. ${ }^{-1} \mathrm{~min}^{-1}$, respectively (Kim \& Lee, 1994).

Measurement of cell growth. Biomass was estimated periodically as dried cell weight determined as follows : cells collected by vacuum filtration (Whatman filter paper GF/C) were washed with 2 vols distilled water and dried at $80^{\circ} \mathrm{C}$ for $24 \mathrm{~h}$.

Measurement of glucose and protein concentration. Glucose was determined by the dinitrosalicylic acid method (Miller, 1959). Protein was determined by the dye-binding method (Bradford, 1976).

$\boldsymbol{\beta}$-Lactamase and $\boldsymbol{\beta}$-lactamase inhibitor assays. $\boldsymbol{\beta}$-Lactamase activity was estimated at $\mathrm{pH} 7.0$ and $37^{\circ} \mathrm{C}$ by a modified iodometric method (Sawai et al., 1978). $\beta$-Lactamase-inhibitory activity $(\%)$ was calculated as $[(A-B) / A] \times 100$, where $A$ is the $\beta$-lactamase activity without inhibitor and $\mathrm{B}$ is the $\beta$ lactamase activity with inhibitor. One unit of $\beta$-lactamaseinhibitory activity was defined as the amount of inhibitor needed for $50 \%$ inhibition of $2 \times 10^{4} \mathrm{U} \beta$-lactamase (Bactopenase; Difco). $\beta$-Lactamase-inhibitory activity in solid culture was estimated using a bioassay procedure as described elsewhere (Jensen et al., 1982).

Protein purification and $\mathbf{N}$-terminal amino acid sequence determination. BLIP-II from the culture supernatant of $S$. exfoliatus SMF19 was purified as described previously (Kim \& Lee, 1994). SDS-PAGE was carried out with $12 \%$ polyacrylamide gels as described by Laemmli (1970). The Nterminal amino acid sequence of BLIP-II was determined by a modified phenylthiohydantoin method using a Milligen/ Biosearch 6600 Prosequencer (Millipore) (Matsudaira, 1987).
DNA manipulation. General methods for DNA manipulations in Streptomyces spp. were performed as described by Hopwood et al. (1985). For large-scale purification of cosmid and plasmid DNA, an alkaline lysis method was used (Sambrook et al., 1989). Small-scale preparation of plasmid DNA, transformation of $E$. coli and construction of recombinant cosmids and plasmids also followed the procedures described by Sambrook et al. (1989). To construct a library of S. exfoliatus SMF19 DNA in the cosmid vector pWE15, $100 \mu \mathrm{g}$ of $S$. exfoliatus SMF19 chromosomal DNA was first partially digested with Sau3AI (Poscochem). The digestion mixture was fractionated on a $10-40 \%$ sucrose density gradient. Fractions containing DNA fragments of $40-60 \mathrm{~kb}$ were pooled and the DNA was precipitated with ethanol. A sample $(500 \mathrm{ng})$ of this DNA was then ligated with $1.4 \mu \mathrm{g}$ BamHI-digested pWE15 that had been treated with calf intestinal alkaline phosphatase (Poscochem). After incubation at $16^{\circ} \mathrm{C}$ for $12 \mathrm{~h}$, DNA from the ligation mixture was packaged in $\lambda$-particles using a Giga Pack II kit (Stratagene) and was transduced into E. coli DH5 $\alpha$.

E. coli colonies containing recombinant cosmids were screened for hybridization to a degenerate 36-mer oligonucleotide probe based on the N-terminal amino acid sequence of BLIPII (Genosys). The probe was labelled with the ECL 3'oligolabelling kit (Amersham). Southern hybridization, colony hybridization and physical mapping of the selected recombinant plasmid were performed using standard techniques (Sambrook et al., 1989).

DNA sequence and analysis. Both DNA strands were sequenced by the dideoxy method of Sanger et al. (1977), using Sequenase 2 and 7-deaza-GTP in place of dGTP to relieve compressions. The DNA sequence of each fragment was determined repeatedly to provide unequivocal results in regions of high $\mathrm{G}+\mathrm{C}$ content. DNA fragments of various sizes were generated with an exonuclease III deletion kit (Promega), and the sequences of those fragments were assembled into a complete sequence using the DNASIS program (Hitachi).

The nucleotide sequence data were also analysed with the DNASIS program to identify restriction sites and regions of dyad symmetry; analysis of codon usage was used to detect ORFs. Protein sequence was deduced from the DNA sequence and examined using FASTP (Pearson \& Lipman, 1988) and the available protein sequence databases.

PCR amplification. Reaction mixtures contained $500 \mathrm{nM}$ each of the forward and reverse primers, $0.2 \mathrm{mM}$ dNTPs, $10 \%$ $(\mathrm{v} / \mathrm{v}) \mathrm{DMSO}, 1 \times$ Taq polymerase reaction buffer (Poscochem), less than $100 \mathrm{ng}$ of template DNA and $0.5 \mathrm{U} \mathrm{Taq}$ polymerase (Poscochem) per $100 \mu \mathrm{l}$ at various $\mathrm{MgCl}_{2}$ concentrations $(0-3.0 \mathrm{mM})$. The mixture was subjected to 30 cycles of $1 \mathrm{~min}$ denaturation at $94^{\circ} \mathrm{C}, 1 \mathrm{~min}$ annealing at 37 or $42{ }^{\circ} \mathrm{C}$ and $1.5 \mathrm{~min}$ extension at $72{ }^{\circ} \mathrm{C}$. Reaction mixtures $(5-10 \mu \mathrm{l})$ were analysed by electrophoresis on $1.2 \%$ agarose gels.

Induction of bliB and refolding of the recombinant BLIP-II protein overexpressed in E. coli. Synthesis of bliB under the control of the T7 promoter was induced as described elsewhere (Sambrook et al., 1989). The BLIP-II protein was overexpressed in E. coli and refolded as follows. After induction with IPTG, cells were harvested by centrifugation and washed once with washing buffer (50 $\mathrm{mM}$ Tris/ $\mathrm{HCl} \mathrm{pH} \mathrm{8.0,2} \mathrm{mM}$ EDTA) in a volume of one half that of the starting culture. The cells were frozen at $-50^{\circ} \mathrm{C}$, thawed in $3 \mathrm{ml}$ washing buffer and disrupted by sonication with 5 cycles of $10 \mathrm{~s}$ pulses followed by $10 \mathrm{~s}$ pauses. Sonicates were centrifuged at $4{ }^{\circ} \mathrm{C}$ and $10000 \mathrm{~g}$, and the supernatant was used as the soluble fraction. The pellet was washed with $3 \mathrm{ml}$ lysis buffer $(50 \mathrm{mM}$ 
Tris/ $\mathrm{HCl} \mathrm{pH} \mathrm{8.0,} 10 \mathrm{mM}$ EDTA, 0.5\% Triton X-100). After centrifugation, the pellet was used as the insoluble fraction and solubilized for $30 \mathrm{~min}$ at $4{ }^{\circ} \mathrm{C}$ with a buffer $(50 \mathrm{mM}$ Tris/ $\mathrm{HCl} \mathrm{pH} \mathrm{8 \cdot 0,1} \mathrm{mM} \mathrm{EDTA,} 100 \mathrm{mM} \mathrm{NaCl}$ ) supplemented with $4 \mathrm{M}$ urea. It was then centrifuged. The supernatant was collected and concentrated with Centriplus-10 (Amicon). The concentration of urea was decreased twofold by adding an equal volume of $5 \mathrm{mM}$ potassium phosphate buffer $\mathrm{pH} 7 \cdot 0$ and the solution was again concentrated with Centriplus- 10 . This step was repeated four times and then the sample was dialysed against $5 \mathrm{mM}$ phosphate buffer $\mathrm{pH} 7 \cdot 0$. The dialysate was analysed by SDS-PAGE and assayed for $\beta$-lactamase inhibition.

\section{RESULTS}

\section{Cloning the gene encoding BLIP-II}

BLIP-II produced in cultures of S. exfoliatus SMF19 was purified by sequential chromatography on hydroxylapatite, anion exchange and gel permeation columns (Kim \& Lee, 1994). SDS-PAGE of the purified BLIP-II is shown in Fig. 1. The $\mathrm{N}$-terminal amino acid sequence was determined to be $\mathrm{NH}_{2}$-Ala-Thr-Ser-Val-Val-AlaTrp-Gly-Gly-Asn-Asn-Asp. A degenerate 36-mer oligonucleotide $\left[5^{\prime} \mathrm{GC}(\mathrm{G} / \mathrm{C}) \mathrm{AC}(\mathrm{G} / \mathrm{C}) \mathrm{TC}(\mathrm{G} / \mathrm{C}) \mathrm{GT}(\mathrm{G} / \mathrm{C})\right.$ GTCGCGTGGGGCGGCAACAACGAC-3'] based on the $\mathrm{N}$-terminal 12 amino acid residues was synthesized and used as a probe in Southern and colony hybridization procedures. Sau3A1-digested fragments of $S$. exfoliatus SMF19 chromosomal DNA were ligated into a cosmid vector ( $\mathrm{pWE15}$ ). The ligated DNA was packaged in $\lambda$-particles using a Giga Pack II kit (Stratagene) and was transduced into E. coli DH5 . About 8000 colonies were picked as a genomic library of $S$. exfoliatus SMF19. Fourteen of them hybridized strongly with the DNA probe in colony hybridizations. Recombinant cosmid DNAs purified from the selected colonies were digested with $A p a \mathrm{I}$ and a $4 \mathrm{~kb}$ DNA fragment that hybridized to the probe was subcloned into a plasmid (pZero-2) to give the recombinant plasmid pSMF251.

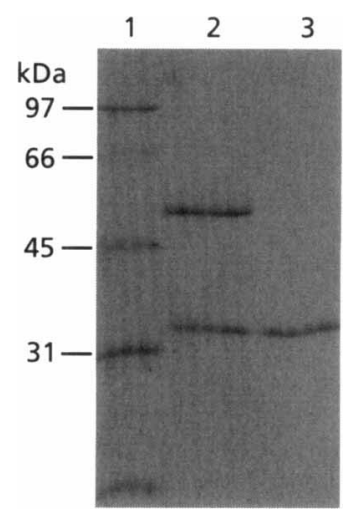

Fig. 1. SDS-PAGE of the BLIP-II protein. Lanes; 1, molecular mass markers; 2, BLIP-II after anion-exchange chromatography; lane 3, BLIP-II after gel permeation chromatography.

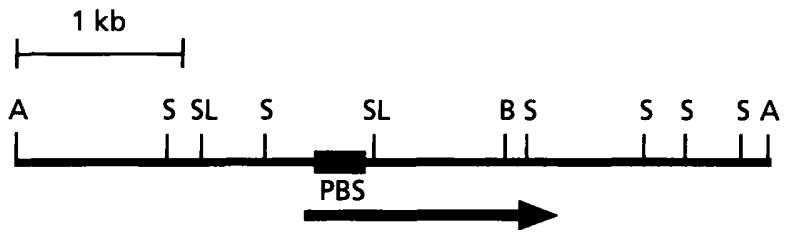

Fig. 2. Physical map of the $4 \mathrm{~kb}$ Apal fragment containing bliB from $S$. exfoliatus SMF19. The fragment was ligated into the Apal site of pZero-2 to yield the plasmid pSMF251. The DNA probe binding site (PBS) is indicated by the black box. The position and orientation of the bliB gene are indicated by the arrow. A, Apal; B, BamHI; S, Sacll; SL, Sall.

\section{Nucleotide sequence and amino acid sequence analyses}

A restriction map of the ApaI DNA fragment and the location of $b l i B$ are presented in Fig. 2. The nucleotide sequence of $b l i B$ was determined and is available from GenBank (accession number U97057). The correct reading frame was initially recognized by the presence of a DNA sequence which corresponded precisely to the $\mathrm{N}$ terminal amino acid sequence of BLIP-II. By analysis using the DNASIS program, three nested ORFs were identified: the first started with an ATG codon at nt 476, the second with GTG at nt 521 and the third with ATG at nt 524. The ATG codon at nt $\mathbf{4 7 6}$ was chosen as the likely translation initiation site since it is preceded by a potential RBS (GAGG; Bibb \& Cohen, 1982) and followed by a typical leader-peptide-encoding sequence (Table 1) observed in other secreted proteins of Streptomyces spp. (Doran et al., 1990; Garcia-Gonzalez et al., 1991). The ORF was terminated by TAG at nt 1592 . Its overall $\mathrm{G}+\mathrm{C}$ content was $73 \mathrm{~mol} \%$; the values for codon positions 1,2 and 3 were 68,59 and $89 \mathrm{~mol} \%$, respectively.

With these assumptions, bliB (1116 bp) encodes 372 amino acids, of which $8.2 \%$ are acidic, $8.2 \%$ are basic and $62.8 \%$ are hydrophobic. The deduced precursor protein has a 40 amino acid leader peptide and gives a mature protein of 332 amino acids with a calculated molecular mass of $33335.9 \mathrm{Da}$. This corresponds well to the molecular mass $(33 \mathrm{kDa})$ determined by SDS-PAGE of the protein. The leader peptide contained three positively charged amino acids (two arginines at positions 7 and 10 and a histidine at position 9), followed by a long hydrophobic stretch from position 11 to 32 (Table 1). Analysis of the deduced amino acid sequence of the ORF showed six tandem repeats of a domain of 40 amino acids that were highly conserved (Fig. 3).

\section{Expression of bliB in E. coli}

bliB was amplified by PCR using the forward primer (FP1) 5' GTTGACATATGCCGAACGGAATCGTC 3' and the reverse primer (RP) 5' GGTAAGATCTCTACGCCGCCCATCTGGA $3^{\prime}$. As shown in Fig. 4, the FP1 primer was designed to include an NdeI site 
Table 1. Signal sequences of Streptomyces proteins

\begin{tabular}{|c|c|c|c|c|}
\hline Protein & Signal sequence* & Length & Source & Reference \\
\hline BLIP-II & $\begin{array}{l}\text { fM P N G IVR L H R F A A L VMS } \\
\underline{\text { GLLSALSAAPGVAAEPSSVS }} \\
\text { VA }\end{array}$ & 40 & S. exfoliatus SMF19 & This study \\
\hline BLIP & $\begin{array}{l}\text { fM R T V G I G G V R R L G R } \\
\text { A V VMAAAVGGLVLGSA A } \\
\text { S N A }\end{array}$ & 36 & S. clavuligerus & Doran et al. (1990) \\
\hline Streptavidin & $\begin{array}{l}\text { fM R K IVVA A I A V S L T TV S I T A } \\
\text { SA S A }\end{array}$ & 24 & S. avidinii & Argarana et al. (1986) \\
\hline$\alpha$-Amylase & $\begin{array}{l}\text { fM Q Q R S R VLGGTLAGIV } \\
\text { AAAAATVAPW P QA }\end{array}$ & 30 & S. hygroscopicus & Hoshiko et al. (1987) \\
\hline $\begin{array}{l}\alpha \text {-Amylase inhibitor } \\
\text { (Tendamistat) }\end{array}$ & $\begin{array}{l}\text { fM R VRALRLAALVGAG } \\
\text { A ALALSPLAAGPASA }\end{array}$ & 30 & S. tendae & Koller \& Riess (1987) \\
\hline Tyrosinase (mel $\mathrm{C} 1)$ & $\begin{array}{l}\text { fM PELTRR RALGAAA } \\
\text { VVAAGVPLVALPAARA }\end{array}$ & 30 & S. antibioticus & Bernan et al. (1985) \\
\hline Agarase $(\operatorname{dag} A)$ & $\begin{array}{l}\text { fMVNARDLIKW S A VAL } \\
\text { GAGAGLAGPAPAAHA }\end{array}$ & 30 & S. coelicolor A3 $(2)$ & Buttner et al. (1987) \\
\hline $\begin{array}{l}\alpha \text {-Amylase inhibitor } \\
\text { (Haim II) }\end{array}$ & $\begin{array}{l}\text { fMKR YVCSTFVACVMVLC } \\
\text { VIPASGAAAHEA VAEDAGNR }\end{array}$ & 31 & S. griseosporeus & Nagaso et al. (1988) \\
\hline DD-Peptidase & $\begin{array}{l}\text { fMVSGTVGR GTALGA } \\
\text { VLLALLAVPANAGTAAA }\end{array}$ & 31 & Streptomyces R61 & Deuz et al. (1987) \\
\hline Protease A $(s p r A)$ & $\begin{array}{l}\text { fM T F K F S LSSTSRYAR } \\
\text { LLAVASGLVAAAALATPSAVA }\end{array}$ & 38 & S. griseus & Henderson et al. (1987) \\
\hline Choresterol oxidase & $\begin{array}{l}\text { fV TANNHLSR RRMLGMAA } \\
\text { FGAAALAGGTTIAAPR } \\
\text { AAAAAKSAA }\end{array}$ & 42 & Streptomyces SA-COO & Ishizaki et al. (1989) \\
\hline
\end{tabular}

* Positively charged residues are shown in bold and each series of hydrophobic residues is indicated by underlining.

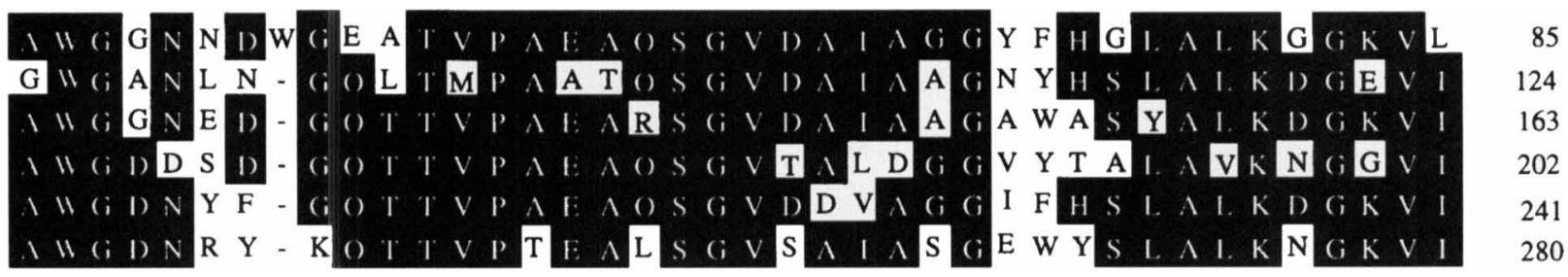

Fig. 3. Alignment of six tandem repeats of a domain of 40 amino acids. The conserved amino acid residues are shown on a black background. Dashes indicate gaps introduced to maximize alignment.

(CATATG) and the RP primer a BglII site (AGATCT). The PCR product was digested with NdeI and $B g l I I$ and subcloned into the expression vector pET3a at the NdeI and BamHI sites. The recombinant plasmid (pSMF268) was used to transform E. coli BL21 (DE3).

A transformant harbouring pSMF268 was cultured in LB medium supplemented with IPTG. From the SDSPAGE patterns of clarifed cell sonicates (Fig. 5), it was apparent that a $35 \mathrm{kDa}$ protein was produced in large amounts (about $25 \%$ of total cell protein) only in the culture of pSMF268 with IPTG present (lane 4). The protein was detected in the insoluble fraction, indicating that the protein was induced and accumulated in inclusion bodies. This protein was extracted with urea and refolded by step-wise removal of the urea. The refolded protein showed $\beta$-lactamase-inhibitory activity in both the iodometric assay (data not shown) and the agar diffusion bioassay (Fig. 6).

\section{Expression of bliB in S. lividans}

To express $b l i B$ under the control of the melC1 promoter

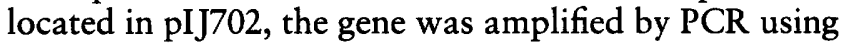
the forward primer (FP2) 5' TTGATGCATGCCGAACGGAATCGTCCGA $3^{\prime}$ and the same reverse primer (RP) as used to construct pSMF268. The FP2 primer was designed to introduce an SphI site (GCATGC) into the PCR product. The PCR product was digested with $S p h I$ and BglII and subcloned into pIJ702 at the SphI and 


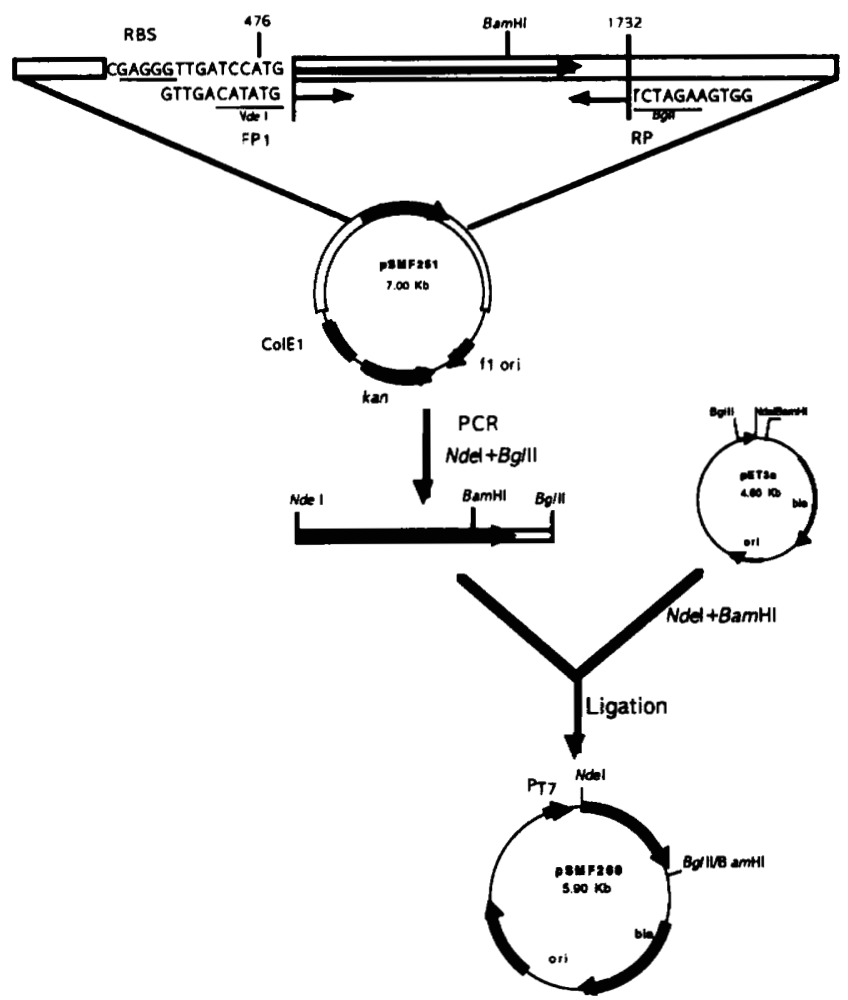

Fig. 4. Construction of pSMF268. bliB was inserted downstream of the T7 promoter $\left(P_{T 7}\right)$ located in PET3a. The putative start codon (ATG) was part of an Ndel site. bliB is indicated by the solid bar which immediately follows the ATG start codon. The primers used for PCR amplification are denoted by the letters FP1 and RP, and arrows represent their orientations.

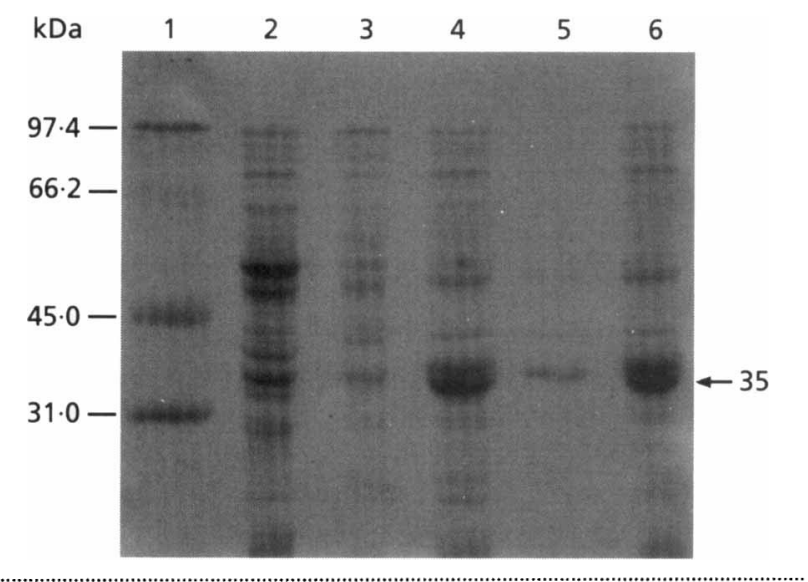

Fig. 5. SDS-PAGE of recombinant BLIP-II protein from $E$. coli BL21 (DE3) containing pSMF268. Lanes: 1, molecular mass markers; 2, pET3a; 3, pSMF268, uninduced; 4, pSMF268, induced; 5, pSMF268, induced, soluble fraction; 6, pSMF268, induced, insoluble fraction.

BglII sites. The recombinant plasmid pSMF267 was then used to transform S. lividans TK24.

To demonstrate heterologous expression of bliB, $S$. lividans TK24 (pSMF267) was grown in BLI production

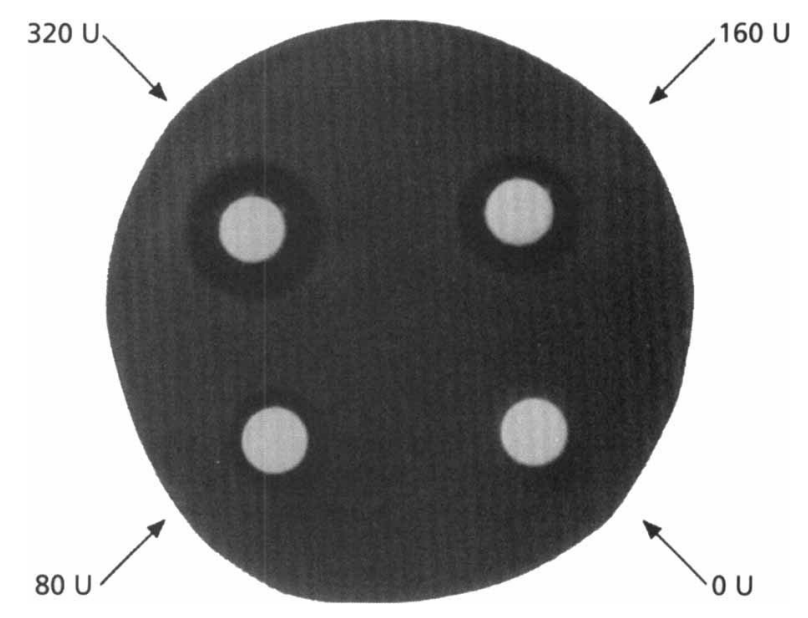

Fig. 6. $\beta$-Lactamase-inhibitory activity of the BLIP-II protein refolded from inclusion bodies of $E$. coli BL21 (DE3). Units of recombinant BLIP-II protein were determined by an iodometric assay. Isolated inclusion bodies were solubilized by treatment with urea and proteins were renatured by stepwise removal of urea.

medium. For comparison, S. lividans TK24 was grown in the same medium. Changes in glucose concentration, $\beta$-lactamase-inhibitory activity and biomass formation in the two cultures are compared in Fig. 7. Since BLIP-II activity was detected only in the recombinant strain, it was concluded that bliB encoded BLIP-II and that the gene was expressed in both $E$. coli and $S$. lividans.

\section{DISCUSSION}

The molecular mass and amino acid sequence of BLIPII were not similar to those of BLIP produced by $S$. clavuligerus (Doran et al., 1990), suggesting that BLIP-II is a different protein. However, the length and position of the positively charged and hydrophobic residues of the leader peptide of BLIP-II resemble those of the leader peptides of BLIP and of other secreted proteins from Streptomyces spp. (Doran et al., 1990; Garcia-Gonalez et al., 1991).

Pairwise comparison (Pearson \& Lipman, 1988) of the deduced amino acid sequence of BLIP-II with sequences in the SWISS-PROT database showed similarities between BLIP-II and two eukaryotic proteins. With the PIM1 protein of Schizosaccharomyces pombe it showed $29.9 \%$ identity and with the RCC1 protein in Candida albicans $28.9 \%$ identity. Both eukaryotic proteins are regulators of chromosome condensation involved in the control of mitosis (Matsumoto \& Beach, 1991; Sazer \& Nurse, 1994). BLIP-II also contains a domain that is repeated six times within the polypeptide (Fig. 3). These repetitions are also found in PIM1 and RCC1 (Matzumoto \& Beach, 1991; Dasso, 1993). However, the functional implication of the 40 amino acid repeats is unclear.

Several biological roles have been proposed for BLIP of S. clavuligerus (Doran et al., 1990): one was that BLIP 


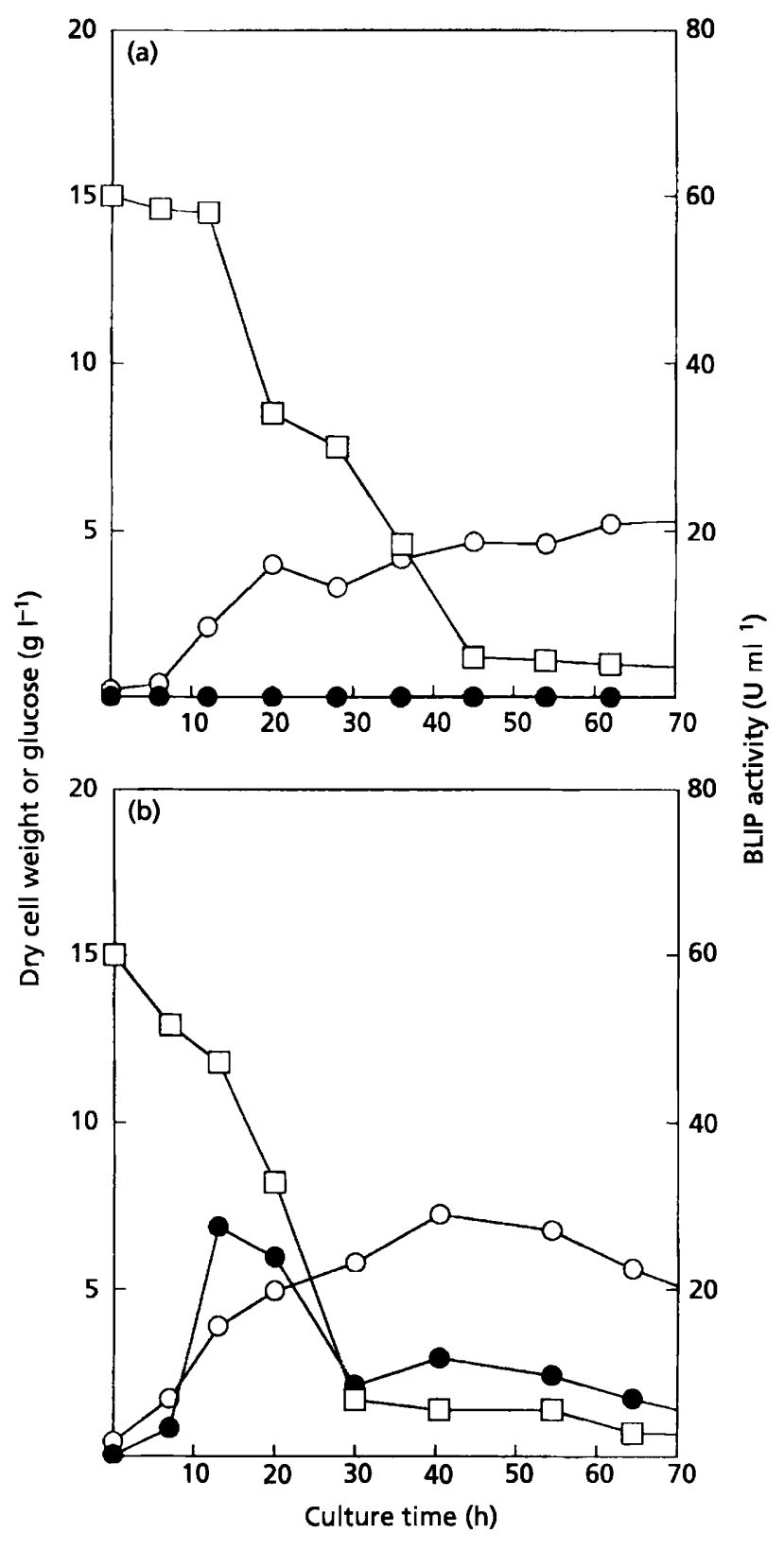

Fig. 7. Growth (O), production of BLIP-II (O) and glucose utilization ( $\square$ ) in batch cultures of S. lividans TK24 (a) and S. lividans(pSMF267) (b).

functions as a protector of autogenous $\beta$-lactam antibiotics from $\beta$-lactamase produced by other organisms in the soil microenvironment; another was that it functions as a regulator of cell growth or morphogenesis. These are reasonable hypotheses for $S$. clavuligerus, which produces $\beta$-lactam antibiotics, including penicillin $\mathrm{N}$ and cephamycin $\mathrm{C}$, and the small-molecule $\beta$ lactamase inhibitor clavulanic acid. However, no $\beta$ lactam antibiotic was detected in the culture filtrate of $S$. exfoliatus SMF19, so the biological role of BLIP-II is unlikely to be the protection of autogenous antibiotics; a role in regulating cell growth or morphogenesis remains a possibility. Further experiments, including gene disruption, are required to understand the biological role of BLIP-II.

When the BLIP-II gene was expressed in E. coli, BLIP-II with its own leader peptide was not secreted into the periplasmic space but accumulated in inclusion bodies, the activity of which was restored after extraction and refolding. This result indicated either that the presence of the leader peptide in BLIP-II played no role in translocation of the precursor protein, or that the precursor protein was not post-translationally processed.

When BLIP-II was expressed in S. lividans(pSMF267), production was maximal early in exponential growth and then decreased drastically. The mechanisms responsible for this instability are unclear. Previous studies have shown that the decrease in heterologous expression of genes encoding $\beta$-lactamase $(b l a)$ and tyrosinase $(m e l)$ that occurred during exponential growth in S. lividans was caused by changes in cultural conditions (Erpicum et al., 1989; Gardner \& Cadman, 1989), so similar effects may be occurring here.

\section{ACKNOWLEDGEMENTS}

This research was supported by a grant from the Science \& Technology Policy Institute (STEPI). The authors are grateful for this support. We thank also the Research Center for Molecular Microbiology (RCMM) for partial support.

\section{REFERENCES}

Abraham, E. P. (1983). History of $\beta$-lactam antibiotics. In Antibiotics Containing the $\beta$-Lactam Structure, Part 1, pp. 1-4. Edited by A. L. Demain \& N. A. Solomon. Springer: Berlin.

Argarana, C. E., Kuntz, I. D., Birken, S., Axel, R. \& Cantor, C. R. (1986). Molecular cloning and nucleotide sequence of the streptavidin gene. Nucleic Acids Res 14, 1871-1882.

Bernan, V., Filpula, D., Herber, W., Bibb, M. \& Katz, E. (1985). The nucleotide sequence of the tyrosinase gene from Streptomyces antibioticus and characterization of the gene product. Gene 37, 101-110.

Bibb, M. J. \& Cohen, S. (1982). Gene expression in Streptomyces: construction and application of promoter probe plasmid vectors in Streptomyces lividans. Mol Gen Genet 187, 265-277.

Bradford, M. M. (1976). A rapid and sensitive method for the quantitation of microgram quantities of protein utilizing the principle of protein-dye binding. Anal Biochem 72, 248-254.

Brown, A. G., Butterworth, D., Hanscomb, G., Hood, J. D., Reading, C. \& Rolinson, G. N. (1976). Naturally occurring $\beta$ lactamase inhibitors with antibacterial activity. $J$ Antibiot 29, 668-669.

Butterworth, D., Cole, M., Hanscomb, G. \& Rolinson, G. N. (1979). Olivanic acids, a family of $\beta$-lactam antibiotics with $\beta$-lactamaseinhibitory properties produced by Streptomyces species. I. Detection, properties and fermentation studies. J Antibiot 32, 287-294.

Buttner, M. J., Fearnley, I. M. \& Bibb, M. J. (1987). The agarase gene (dagA) of Streptomyces coelicolor A3(2): nucleotide sequence and transcriptional analysis. Mol Gen Genet 209, 101-109.

Dasso, M. (1993). RCC1 in the cell cycle: the regulator of chromosome condensation takes on new roles. Trends Biochem Sci 18, 96-101. 
Doran, J. L., Leskiw, B. K., Aippersbach, S. \& Jensen, S. E. (1990). Isolation and characterization of a $\beta$-lactamase-inhibitory protein from Streptomyces clavuligerus and cloning and analysis of the corresponding gene. J Bacteriol 172, 4909-4918.

Deuz, C., Piron-Fraipont, C., Joris, B., Dusart, J., Urdea, M. S., Martial, J. A., Frere, J.-M. \& Ghuysen, J.-M. (1987). Primary structure of the Streptomyces R61 extracellular DD-peptidase. 1. Cloning into Streptomyces lividans and nucleotide sequence of the gene. Eur J Biochem 162, 509-518.

Erpicum, T., Granier, B., Delcour, M., Lenzini, V. M., MguyenDisteche, M., Dusart, J. \& Frere, J.-M. (1989). Enzyme production by genetically engineered Streptomyces strains: influence of culture conditions. Biotechnol Bioeng 35, 719-726.

Garcia-Gonzalez, M. D., Martin, J. F., Vial, T. \& Liras, P. (1991). Characterization, expression in Streptomyces lividans, and processing of the amylase of Streptomyces grieseus IMRU 3570: two different amylases are derived from the same gene by an intracellular processing mechanism. $J$ Bacteriol 173, 2451-2458.

Gardner, A. R. \& Cadman, T. W. (1989). Product deactivation in recombinant Streptomyces. Biotechnol Bioeng 36, 243-251.

Hanahan, D. (1983). Studies on transformation of Escherichia coli with plasmids. $J$ Mol Biol 166, 557-580.

Hata, T., Omura, S., Iwaw, Y., Ohno, H., Takeshima, T. \& Yamaguchi, N. (1972). Studies on penicillinase inhibitors produced by microorganisms. J Antibiot 25, 473-474.

Henderson, G., Krygsman, P., Liu, C. J., Davey, C. C. \& Malek, L. T. (1987). Characterization and structure of gene for proteases A and B from Streptomyces griseus. J Bacteriol 169, 3779-3784.

Hopwood, D. A., Bibb, M. J., Chater, K. F. \& 7 other authors (1985). Genetic Manipulation of Streptomyces: a Laboratory Manual. Norwich: John Innes Foundation.

Hoshiko, S., Makabe, O., Nojiri, C., Katsumata, K., Satoh, E. \& Nagaoka, K. (1987). Molecular cloning and characterization of the Streptomyces hygroscopicus $\alpha$-amylase gene. J Bacteriol 169, 1029-1036.

Ishizaki, T., Hirayama, N., Shinkawa, H., Nimi, O. \& Murooka, Y. (1989). Nucleotide sequence of the gene for cholesterol oxidase from a Streptomyces sp. J Bacteriol 171, 596-601.

Jensen, S. E., Westlake, D. W. S. \& Wolfe, S. (1982). Cyclization of $\delta$-(L- $\alpha$-aminoadipyl)-L-cysteinyl-D-valine to penicillins by cell-free extracts of Streptomyces clavuligerus. J Antibiot 35, 483-490.

Jones, K. L. (1949). Fresh isolates of actinomycetes in which the presence of sporogenous aerial mycelia is a fluctuating characteristic. J Bacteriol 57, 141-145.

Kahan, K. S., Kahan, F. M., Goegelman, R. \& 10 other authors (1979). Thienamycin, a new $\beta$-lactam antibiotic. I. Discovery, taxonomy, isolation and physical properties. J Antibiot 32, 1-12.

Katz, E., Thompson, C. J. \& Hopwood, D. A. (1983). Cloning and expression of the tyrosinase gene from Streptomyces antibioticus in Streptomyces lividans. J Gen Microbiol 129, 2703-2714.

Kim, M. K. \& Lee, K. J. (1994). Characteristic of $\beta$-lactamaseinhibiting proteins from Streptomyces exfoliatus SMF19. Appl Environ Microbiol 60, 1029-1032.

Kim, M. K., Kang, H. I. \& Lee, K. J. (1991). Purification and characterization of proteinaceous $\beta$-lactamase inhibitor from the culture broth of Streptomyces sp. SMF19. J Microb Biotechnol 1, $85-89$.

Koller, K.-P. \& Riess, G. (1987). Heterologous expression of the $\alpha$-amylase inhibitor gene cloned from an amplified genomic sequence of Streptomyces tendae. J Bacteriol 171, 4953-4957.

Laemmli, U. K. (1970). Cleavage of structural proteins during the assembly of the head of bacteriophage T4. Nature 227, 680-685.

Matsudaira, P. (1987). Sequence from picomole quantities of proteins electroblotted onto polyvinylidene difluoride membranes. J Biol Chem 262, 10035-10038.

Matsumoto, T. \& Beach, D. (1991). Premature initiation of mitosis in yeast lacking RCC1 or an interacting GTPase. Cell 66, 347-360.

Miller, G. L. (1959). Use of dinitrosalicylic acid reagent for determination of reducing sugar. Anal Chem 31, 426-428.

Nagaso, H., Saito, S., Saito, H. \& Takahashi, H. (1988). Nucleotide sequence and expression of a Streptomyces grieseus proteinaceous $\alpha$-amylase inhibitor (Haim II) gene. J Bacteriol 170, 4451-4457.

Neu, H. C. (1992). The crisis in antibiotic resistance. Science 257, 1064-1072.

Pearson, W. R. \& Lipman, D. J. (1988). Improved tools for biological sequence comparison. Proc Natl Acad Sci USA 85, 2444-2448.

Sambrook, J., Fritsch, E. F. \& Maniatis. T. (1989). Molecular Cloning: a Laboratory Manual, 2nd edn. Cold Spring Harbor, NY: Cold Spring Harbor Laboratory.

Sanger, F., Nicklen, S. \& Coulson, A. R. (1977). DNA sequencing with chain-terminating inhibitors. Proc Natl Acad Aci USA 74, 5463-5467.

Sawai, T., Takahashi, T. \& Yamagashi, S. (1978). Iodometric assay method for $\beta$-lactamase with various $\beta$-lactam antibiotics as substrates. Antimicrob Agents Chemother 13, 910-913.

Sazer, S. \& Nurse, P. (1994). A fission yeast RCC1-related protein is required for the mitosis to interphase transition. $E M B O \mathrm{~J} 13$, 606-615.

Strynadka, N. C. J., Jensen, S. E., Johns, K., Blanchard, H., Page, M., Maragne, A., Frere, J.-M. \& James, M. N. G. (1994). Structural and kinetic characterization of a $\beta$-lactamase-inhibitor protein. Nature 368, 657-660.

Strynadka, N. C. J., Jensen, S. E., Alzari, P. M. \& James, M. N. G. (1996). A potent new mode of $\beta$-lactamase inhibition revealed by the $1.7 \AA$ X-ray crystallographic structure of the TEM-1-BLIP complex. Nat Struct Biol 3, 290-297.

Studier, F. W. \& Moffatt, B. A. (1986). Use of bacteriophage T7 RNA polymerase to direct selective high-level expression of cloned genes. J Mol Biol 189, 113-117.

Wahl, G. M., Lewis, K. A., Ruiz, J. C., Rothenberg, B., Zhao, J. \& Evans, G. A. (1987). Cosmid vectors for rapid genomic walking, restriction mapping, and gene transfer. Proc Natl Acad Sci USA 84, 2160-2164.

Yanisch-Perron, C., Vieira, J. \& Messing, J. (1985). Improved M13 phage cloning vectors and host strains: nucleotide sequences of the M13mp18 and pUC19 vectors. Gene 33, 103-119.

Received 9 January 1998; revised 24 April 1998; accepted 1 May 1998. 